\section{Large-scale effects of forest management in Mediterranean landscapes of Europe}

\author{
Raffaele Lafortezza ${ }^{(1)}$, Giovanni Sanesi ${ }^{(1)}$, Jiquan Chen ${ }^{(2)}$
}

Forest landscapes are fundamental components of the living environment and consist of complex assemblages of forest and non-forest elements whose arrangement reflects, in part, the magnitude, intensity, and type of management. Because forests change across regions and scales, a variety of approaches have been proposed to support research and applicable goals. The most promising way to analyze forest landscapes is through the application of the landscape ecological approach, which is the study of ecological patterns and processes in heterogeneous, mostly human-modified, landscapes. In this paper, we analyze the role of landscape ecology in the context of forest landscapes. We discuss the main factors related to forest management which may affect landscape composition and configuration by referencing examples from the Mediterranean landscapes of Europe. Finally, we discuss the key issues for incorporating landscape ecological principles into forest planning and management and provide directions for future research in the emerging context of ecosystem services.

Keywords: Forest Management, Landscape Ecology, Forest Landscapes, Mediterranean Regions, Human Disturbances

\section{Introduction}

In recent decades, landscape ecology has advanced with rapid developments in technology and data, models and applications, increased knowledge exchange among disciplines, availability of spatial data and analytical methods, and growing number of education programs that include significant components of landscape ecology (Wu \& Hobbs 2007, McGarigal et al. 2009, Ager et al. 2010, Lavorel et al. 2011). It has now reached a stage of maturity that principles and models can be applied with confidence in real cases (Kurttila 2001, Mendoza et al. 2005, Suzuki \& Olson 2008).

A growing number of agencies and orga-

(1) Dipartimento di Scienze AgroAmbientali e Territoriali, Università degli Studi di Bari “A. Moro", v. Amendola 165/A, I-70126 Bari (Italy); (2) Landscape Ecology and Ecosystem Science (LEES) Lab, University of Toledo, Ohio (USA)

@ Raffaele Lafortezza

(raffaele.lafortezza@uniba.it)

Received: Jan 31, 2013 - Accepted: Apr 30 2013

Citation: Lafortezza R, Sanesi G, Chen J, 2013. Large-scale effects of forest management in Mediterranean landscapes of Europe. iForest 6: 342-346 [online 2013-08-

29] URL: http://www.sisef.it/iforest/ contents/?id=ifor0960-006

Communicated by: Luca Salvati by determining how forest harvesting or other management practices may affect the mechanisms underlying species diversity at landscape scales (Kurttila 2001, González et al. 2010).

Recognizing these developments, we analyze the role of landscape ecology in the context of forest management. We analyze the main factors related to forest management which may affect landscape composition and configuration using examples from the Mediterranean landscapes of Europe (Torras \& Saura 2008, Puddu et al. 2012). We discuss the key issues for incorporating landscape ecology principles into forest management and provide directions for future research in the emerging context of ecosystem services. Because the goal of promoting multiple services of forests cannot be achieved without considering the landscape context (Moreira \& Russo 2007), we propose this approach to be considered as the core in forest landscape management (Chazdon 2008, Li et al. 2011).

\section{Ecological planning and management of landscapes}

Forest landscapes are difficult to define in a general way because they often consist of a mixture between forest and non-forest elements, such as agricultural fields, roads, water bodies, and different types of vegetation. This is especially true in highly-modified landscapes such as those in the Mediterranean regions of Europe (Makhzoumi \& Pungetti 1999, Grove \& Rackham 2001, Moreira et al. 2011). One of the main characteristics of forest landscapes is the presence of forest-type vegetation with patches of various size, shape, and degree of connectivity (Perera \& Baldwin 2000, Lafortezza et al. 2010). The structure and spatial arrangement of these patches depend largely on their origin (i.e., introduced vs. environmental patches) as well as the surrounding matrix (Forman 1995, Lindenmayer \& Franklin 2002). Interactions among the physical environment, such as soil, landform, climate, hydrology, forest vegetation, and land use jointly affect the composition and configuration of a forest landscape (Van Eetvelde \& Antrop 2004).

In general, landscape composition refers to the relative amount and abundance of landscape elements within a mosaic, whereas landscape configuration refers to the spatial arrangement, location, and functional connectivity of these components (McGarigal et al. 2009). For composition, forest patches represent the basic elements of these landscapes and may affect many ecological processes, including the movement and persistence of species, the susceptibility and spread of disturbances (e.g., wildfires, pest outbreaks), and the redistribution of mate- 
rials and energy (Lindenmayer \& Fischer 2007). One of the basic principles in landscape ecology is that large and heterogeneous forest patches normally support higher levels of ecological processes because large, continuous patches increase the probability of interbreeding among species populations (Kindlmann \& Burel 2008).

As for configuration, complex structure is normally considered to provide more opportunities for organisms dwelling in the landscape for different needs (e.g., foraging). For many fragmented landscapes, such as those in the Mediterranean regions of Europe, in creasing forest connectivity and integrity are needed to facilitate different activity of species (Schooley \& Wiens 2004, Luque et al. 2012). Both composition and configuration are therefore required to understand landscapes during the forest management (Blondel et al. 2010).

In their review, Boutin \& Hebert (2002) discussed how landscape ecology had contributed to shaping current practices in forest management. They concluded that past research efforts were made on two aspects: (1) the effects of forest fragmentation on species conservation; and (2) the development of models to predict the effects of the spatial arrangement of forest patches on ecologica processes. As a consequence, many forest management practices need to be analyzed and implemented at the landscape-scale leve (Scarascia-Mugnozza et al. 2000). In this regard, Kurttila (2001) provides a review of forest plans where spatial objectives have been integrated into forest planning. Mendoza et al. (2005) described a forest plan designed following landscape ecological principles in which silvicultural treatments were planned to accelerate spatial diversification and establish late successional conditions. Chen et al. (2008) identified and discussed the main components and challenges in landscape ecological studies with an emphasis on how they relate to forest management. Among these challenges are issues including scaling, ecosystem interactions (e.g., area-ofedge influence), and landscape modeling (Gustafson \& Crow 1996). In particular, scaling issues represent a key topic that finds relevance in forest management (Corry \& Lafortezza 2007): focusing on a single scale, in time or space, hides important processes which emerge at larger or smaller scales. All of these views point to a single conclusion that planning and management of landscape have to be made within the landscape context.

More recently, research has moved to explore the application of landscape ecology in forest planning and management by developing spatially-explicit projection models (Scheller \& Mladenoff 2007, Ewers et al. 2009) that provide effective tools for planning forests at large scales and allow various forest planning and management scenarios to be projected into the future (Boutin \& Hebert 2002, Euskirchen et al. 2002). The combination of satellite- and ground-based data provides information on forest landscape conditions and enables investigation of the cumulative effects of forest planning and management over time (Wulder et al. 2009).

For example, Geri et al. (2010) investigated large-scale forest dynamics in Mediterranean forest landscapes using a combination of satellite-derived maps, field surveys, and landscape metrics. The authors demonstrated how the abandonment of traditional management and the intensification of land-use practices may lead to the conversion of Mediterranean forest landscapes into homogeneous systems. However, many models produced by researchers are complicated and require large amounts of data for parameterization and validation. Current models are mostly research tools and not particularly useful to those practitioners, such as forest managers seeking to develop feasible planning and management strategies. Nevertheless, scenario testing, in which multiple drivers of change are simulated and the spatial consequences for the property or process of interest are assessed, has the potential to be especially helpful (Chen et al. 2008). For example, Euskirchen et al. (2002) tested the effects of different landscape and disturbance scenarios on forest net ecosystem productivity (NEP) and biomass, finding that the timing of timber harvest significantly affected the degree to which a landscape sequesters carbon.

Major considerations for developing landscape projection models should include an understanding of the main factors related to forest management (i.e., human-induced factors) which may affect forest landscapes in terms of composition and configuration (Stephens et al. 2010, Hladnik \& Pirnat 2011). Understanding these factors is a prerequisite to devise a more realistic and relevant foundation for developing landscape projection models that include forest management practices and their large-scale effects (Wu \& Hobbs 2007, Heller \& Zavaleta 2009, Turner 2010).

\section{Forest management in highly- modified landscapes}

Forest landscapes are heterogeneous systems and therefore their study requires a thoughtful understanding of the main causes of spatial variability and the relative consequences for ecological processes (Turner 1989, 2001). Recent studies in landscape ecology reviewed the main cultural factors affecting forest landscapes. In this regard, Lafortezza et al. (2008) identified four sets of factors, such as: (a) land tenure systems; (b) forest tenure regimes; (c) silvicultural traditions; and (d) management plans. In the following, we describe these factors under a landscape ecological perspective and discuss their large-scale effects using Mediterranean landscapes as cases examples.

Land tenure system is the institutional framework that society creates to make land ownership, use, and management possible and that reflects the level of development in society, economy, and technology (Bruce 1998). In forest landscapes, land tenure is one of the main factors affecting spatial heterogeneity, especially in Mediterranean landscapes where most of the land is owned by smaller, private landowners: forest landscapes are often parceled into patches whose size and shape are related to ownership and land management units (Crow et al. 1999), thus facilitating forest fragmentation and land use conversion (Geri et al. 2010). The patterns of land division and ownership have commonly fragmented primeval forest ecosystems along lines that coincide with roads network, farm boundaries, and settlements. Cyclical disturbances, such as rotational grazing, cutting and coppicing or fire management have gradually led to complex and heterogeneous cultural patterns characterized by relatively small and regular forest patches (Naveh 1995).

Forest tenure regime is the combination of commonly defined forest ownership rights, responsibilities, and other arrangements for the management and use of forest resources (Romano 2007). Forest tenure directly affects the conduct of forest landowners, which, in turn, affects the way forests are planned and managed (Gustafson \& Crow 1996). Securing forest tenure to local communities is indeed a prerequisite to an efficient forest planning and management as it creates common property rights on forest resources (LeMaster \& Owubah 2000, FAO 2006, Zheng et al. 2010). From a landscape ecological perspective, the type of forest tenure regime or ownership may affect landscape configuration and the connectivity of forest patches, thus influencing the degree of spatial heterogeneity as well as the functions of the landscapes. A number of rules affect forest tenure in the Mediterranean regions of Europe: under public ownership rights, trends towards coppice conversion into high forest have substantially increased especially in situation of large publicly-owned lands. On privately-owned forests, conversion is still limited because the small size of forest patches makes high forest systems not economic feasible.

Silvicultural traditions are the methods used by local communities and forest managers for harvesting and regenerating forest stands that produce fuel-wood and other types of products or commodities. Such methods vary according to the particular species, site conditions, silvicultural system, and the type of forest in a given region. These 
methods are often rooted in the traditional knowledge that communities have of forest and land use management (Rotherham 2007). Traditional silvicultural methods are important determinants of forest landscapes as they represent the intrinsic capacity of humans to benefit from forest resources without compromising landscape composition and configuration. Recent studies suggested that the lack of traditional management would negatively affect the response of species to forest patterns, thus limiting the capacity of forest landscapes to support ecological processes (Wulder et al. 2009). This is especially true in the Mediterranean landscapes of Europe: silvicultural practices have been drastically simplified in order to reduce harvesting costs and this is causing the loss of wealth of traditional knowledge that has developed over the millennia (Parrotta \& Agnoletti 2007).

Management plans are those strategies employed by forest professionals, forest-land owners, timber industries, or forest authorities to achieve commodity values, forest conservation, and recreation (Kangas et al. 2000). Management plans could regulate various practices of management (e.g., harvesting, seed-tree, shelter-wood, selective harvesting). When not well-guided by largescale plans, management practices may drive severe changes in the spatial heterogeneity of forest landscapes, thus affecting a number of processes (e.g., flora/fauna dispersal) that are sensitive to spatial patterns. One of the most significant consequences of forest management is credited to large-scale clear-cut logging, where forest composition and configuration are drastically changed, often for the very long term. This process may lead to forest landscapes made of even-aged patches with an overall reduction in the spatial heterogeneity and landscape functionality (Vos \& Stortelder 1992, Grove \& Rackham 2001). Following this approach, recent studies focused on some of the most relevant mechanisms and factors regulating the impact of management on forest landscapes throughout the Mediterranean regions of $\mathrm{Eu}-$ rope. For example, Puddu et al. (2012) analyzed forest changes over almost a century on Sardinia Island, central Italy. The authors identified an increase in forest cover, which can be explained by farmland abandonment afforestation policies, and abandonment of traditional practices. Other studies (e.g., Moreira \& Russo 2007) quantified the role of disturbances in promoting forest landscapes made of patches at different stages of the shrub-forest succession. One way to preserve species diversity in the Mediterranean forest landscapes is through policies specifically designed to prevent land abandonment and keep traditional management (e.g., Falcucci et al. 2007). Torras \& Saura (2008) analyzed the effects of different regeneration and stand improvement treatments on six forest biodiversity indicators in the Mediterranean landscape of Catalonia. They suggested that selection cutting is an appropriate and sustainable regeneration treatment for the Mediterranean forest. However, its implementation should avoid the systematic harvesting of the highest-quality and largest trees (Torras \& Saura 2008). These studies suggest that more emphasis should be placed on preserving and reintroducing traditional land use management activities, simply because Mediterranean landscapes have experienced a long land use history; yet, are disappearing (Blondel et al. 2010).

The pervasive effects of these factors may lead forest landscapes in changing their composition and configuration and gradually convert large forest patches into smaller fragments having more regular shapes (Lafortezza et al. 2010)

\section{Conclusion}

Forest landscapes are one of the most tractable examples of the human influence on pristine ecosystems and habitats: they reflect past and present management activities and, to some degree, the consequence of human disturbance and resource utilization (Bonan 2008, Feld et al. 2009). Human utilization of forest resources, through harvest and land use, has resulted in fragmented forest landscapes and degrading quality in wildlife habitat, biodiversity, and other ecosystem services (Lavorel et al. 2011). However, in many regions human management is critical to the maintenance of forest landscapes (Chen \& Saunders 2006). For example, changes to the socioeconomic conditions may drive the transition of forest landscapes in terms of composition and configuration and this, in turn, could affect ecological processes that depend on management (Collingham \& Huntley 2000). Clearly managing forest landscapes is a difficult task (Krause et al. 2011).

The persistent effects of non-sustainable management practices could limit forest successional patterns and species response to natural disturbances. For example, changing historic disturbance regimes through fire suppression and reforestation has significantly modified the composition and structure of many forest landscapes throughout the Mediterranean (e.g., by altering species dynamics, abundance, and age structure Baker 1993, Boose et al. 2004). Disturbances that begin in the matrix can spread to influence processes in forest patches and this could ultimately affect the dynamics of species and the resulting biodiversity at ecosystem and landscape levels (Lindenmayer \& Franklin 2002).

By focusing on the main factors related to forest management which will affect landscape composition and configuration, forest managers could gain new insights into some of the applicable ecological theory that underlies forest planning and management with a specific focus on the role of humans in shaping landscape patterns and maintaining or altering ecological processes and landscape functions (Mata et al. 2005, Rotherham 2007, Tanentzap et al. 2010). In turn, landscape ecologists could attain enlightenment by practicing their principles and models at the large-scale level, thus facilitating the transfer of knowledge to practitioners and the dissemination of research findings to policymakers or even the general public.

Linking large-scale landscape assessments with knowledge of the main factors influencing composition and configuration could represent an important step forward for the analysis of forest landscapes, thus supporting management activities and actions mitigating disturbances (Blondel et al. 2010).

Cross-disciplinary and cultural backgrounds are therefore required for guiding forest landscape management toward the goal of providing multiple ecosystem services (Chazdon 2008). In this direction, landscape ecology can be seen as the common language between the sciences of ecology, resource management, and land use planning. Through this language, forest planners and managers could strengthen their synergy and devise long-term strategies on how to use and manage forest resources at the landscape level. Landscape ecology should be considered as a way to integrate human ecology and behavior into a broader context, such as the landscape-scale patterns and processes, but also the global scale conditions and influences. With the help of landscape ecology, the outcomes of multiple uses and non-sustainable management practices could be modeled and predicted in a much more integrative fashion, thus providing the mean for considering forest plans and management actions in a much larger cultural, economic, and ecological template. Although challenging, the integration of landscape ecological principles into current management plans and practices could assist the conservation of natural and cultural values (i.e., ecosystem services) in many forested regions of the globe.

Forest landscape management needs to consider the temporal and spatial character of managed disturbance for multi-phase forest conditions. With advancement of landscape knowledge and models, one can predetermine the management practices through scenario tests of various options (e.g., spatial pattern and their evolution over time). This may aid in the understanding of spatially explicit processes like fragmentation and loss of species diversity that have reached substantial levels of concern in many forest landscapes, such as those in the Mediterranean region. 


\section{References}

Ager AA, Vaillant NM, Finney MA (2010). A comparison of landscape fuel treatment strategies to mitigate wildland fire risk in the urban interface and preserve old forest structure. Fores Ecology and Management 259: 1556-1570. doi: $10.1016 /$ j.foreco.2010.01.032

Baker WL (1993). Spatially heterogeneous multi-scale response of landscapes to fire suppression. Oikos 66: 66-71. - doi: 10.2307/3545196

Blondel J, Aronson J, Boudiou JY, Boeuf G (2010). The Mediterranean basin - biological diversity in space and time. Oxford University Press. Oxford, UK.

Bonan GB (2008). Forests and climate change: forcing, feedbacks, and the climate benefits of forests. Science 320: 1444-1449. - doi: 10.1126/ science. 1155121

Boose ER, Serrano MI, Foster DR (2004). Landscape and regional impacts of hurricanes in Puerto Rico. Ecological Monograph 74 (2): 335 352. - doi: 10.1890/02-4057

Boutin S, Hebert D (2002). Landscape ecology and forest management: developing an effective partnership. Ecological Applications 12: 390397. - doi: 10.1890/1051-0761(2002)012[0390 LEAFMD]2.0.CO;2

Bruce JW (1998). Review of tenure terminology. Tenure Briefs 1: 1-8. [online] URL: http://www.minds.wisconsin.edu/bitstream/handle/1793/220 13/73 tb1.pdf

Bunker DE, DeClerck F, Bradford JC, Colwell RK, Perfecto I, Phillips OL, Sankaran M, Naeem S (2005). Species loss and aboveground carbon storage in a tropical forest. Science 310: 10291031. - doi: 10.1126/science. 1117682

Chazdon RL (2008). Beyond deforestation: restoring forests and ecosystem services on degraded lands. Science 320: 1458-1460. - doi: 10.1126/ science. 1155365

Chen J, Saunders SC (2006). Ecology of multiple ecosystems in time and space. In "Ecology of hierarchical landscapes: from theory to application" (Chen J, Saunders SC, Brosofske KD, Crow TR eds). Nova Publishing, Carbondale, IL, USA, pp. 1-34.

Chen J, Brosofske KD, Lafortezza R (2008). Ecology and management of forest landscapes. In "Patterns and processes in forest landscapes: multiple use and sustainable management" (Lafortezza R, Chen J, Sanesi G, Crow TR eds). Springer, The Netherlands, pp. 3-15.

Collingham YC, Huntley B (2000). Impacts of habitat fragmentation and patch size upon migration rates. Ecological Applications 10:131-144. doi: 10.1890/1051-0761(2000)010[0131:IOHFA P]2.0.CO;2

Corry RC, Lafortezza R (2007). Sensitivity of landscape measurements to changing grain size for fine-scale design and management. Landscape and Ecological Engineering 3: 47-53. doi: 10.1007/s11355-006-0015-7

Crow TR, Host GE, Mladenoff DJ (1999). Ownership and ecosystem as sources of heterogeneity in a forested landscape, Wisconsin, USA. Landscape Ecology 14: 449-463. - doi: 10.1023/
A:1008084123874

Crow TR (2005). Landscape ecology and forest management. In: "Issues and perspectives in landscape ecology" (Wiens J, Moss M eds). Cambridge University Press, Cambridge, UK, pp. 201-207 - doi: 10.1017/CBO9780511614415 de Groot RS, Wilson MA, Boumans RMJ (2002). A typology for the classification, description and valuation of ecosystem functions, goods and services. Ecological Economics 41: 393-408. - doi: 10.1016/S0921-8009(02)00089-7

Euskirchen E, Chen J, Li H, Gustafson EJ, Crow TR (2002). Modeling net carbon flows under alternative management regimes at a landscape level. Ecological Modelling 154:75-91. - doi: 10.1016/S0304-3800(02)00052-2

Ewers RM, Kapos V, Coomes DA, Lafortezza R, Didham RL (2009). Mapping community change in modified landscapes. Biological Conservation 142: 2872-2880. - doi: 10.1016/j.biocon.2009.06 .022

Falcucci A, Maiorano L, Boitani L (2007). Changes in land-use/land-cover patterns in Italy and their implications for biodiversity conservation. Landscape Ecology 22: 617-631. - doi: 10.1007/s10980-006-9056-4

FAO (2006). Understanding forest tenure: what rights and for whom? Secure forest tenure for sustainable forest management and poverty alleviation: the case of South and Southeast Asia. Working Paper 14, Forest Policy and Institutions, Food and Agriculture Organization of the United Nations, Rome, pp. 91.

Feld CK, Da Silva PM, Sousa JP, De Bello F, Bugter R, Grandin U, Hering D, Lavorel S, Mountford O, Pardo I, Pärtel M, Römbke J, Sandin L, Jones BK, Harrison P (2009). Indicators of biodiversity and ecosystem services: a synthesis across ecosystems and spatial scales. Oikos 118: 1862-1871. - doi: 10.1111/j.16000706.2009.17860.x

Forman RTT (1995). Land mosaics: The ecology of landscapes and regions. Cambridge University Press, New York, USA.

Geri F, Rocchini D, Chiarucci A (2010). Landscape metrics and topographical determinants of large-scale forest dynamics in a Mediterranean landscape. Landscape and Urban Planning 95 (12): 46-53. - doi: 10.1016/j.landurbplan.2009.12. 001

González E, González-Sanchis M, Cabezas Á, Comín FA, Muller E (2010). Recent changes in the riparian forest of a large regulated Mediterranean river: implications for management. Environmental Management 45: 669-681. - doi: 10.1007/s00267-010-9441-2

Gonzalez M, Ladet S, Deconchat M, Cabanettes A, Alard D, Balent G (2010). Relative contribution of edge and interior zones to patch size effect on species richness: an example for woody plants. Forest Ecology and Management 259: 266-274. - doi: 10.1016/j.foreco.2009.10.010

Grove AT, Rackham O (2001). The nature of mediterranean Europe. An ecological history. Yale University Press, New Haven, CT, USA. Gustafson EJ, Crow TR (1996). Simulating the ef- fects of alternative forest management strategies on landscape structure. Journal of Environmental Management 46: 77-94. - doi: 10.1006/jema. 1996.0008

Heller NE, Zavaleta ES (2009). Biodiversity management in the face of climate change: a review of 22 years of recommendations. Biological Conservation 142: 14-32. - doi: 10.1016/j.biocon. 2008.10.006

Hladnik D, Pirnat J (2011). Urban forestry - linking naturalness and amenity: the case of Ljubljana, Slovenia. Urban Forestry and Urban Greening 10 (2): 105-112. - doi: 10.1016/j.ufug. 2011.02.002

Hodgson JA, Thomas CD, Wintle BA, Moilanen A (2009). Climate change, connectivity and conservation decision making: back to basics. Journal of Applied Ecology 46: 964-969. - doi: 10.1111/j.1365-2664.2009.01695.x

Kangas J, Store R, Leskinen P, Mehtatalo L (2000). Improving the quality of landscape ecological forest planning by utilising advanced decision-support tools. Forest Ecology and Management 132: 157-171. - doi: 10.1016/S03781127(99)00221-2

Kindlmann P, Burel F (2008). Connectivity measures: a review. Landscape Ecology 23 (8): 879890. - doi: 10.1007/s10980-008-9245-4

Krause B, Culmsee H, Wesche K, Bergmeier E, Leuschner C (2011). Habitat loss of floodplain meadows in north Germany since the 1950s. Biodiversity and Conservation 20: 2347-2364. doi: 10.1007/s10531-011-9988-0

Kurttila M (2001). The spatial structure of forests in the optimization calculations of forest planning - a landscape ecological perspective. Forest Ecology and Management 142: 129-142. - doi: 10.1016/S0378-1127(00)00343-1

Lafortezza R, Corry RC, Sanesi G, Brown RD (2008). Cultural determinants of spatial heterogeneity in forest landscapes. In "Patterns and processes in forest landscapes: multiple use and sustainable management" (Lafortezza R, Chen J, Sanesi G, Crow TR eds). Springer, The Netherlands, pp. 17-32.

Lafortezza R, Carrus G, Sanesi G, Davies C (2009). Benefits and well-being perceived by people visiting green spaces in periods of heat stress. Urban Forestry and Urban Greening 8: 97-108. - doi: 10.1016/j.ufug.2009.02.003

Lafortezza R, Coomes DA, Kapos V, Ewers RM (2010). Assessing the impacts of fragmentation on plant communities in New Zealand: scaling from survey plots to landscapes. Global Ecology and Biogeography 19 (5): 741-754. - doi: 10.1111/j.1466-8238.2010.00542.x

Lavorel S, Grigulis K, Lamarque P, Colace M, Garden D, Girel J, Pellet G, Douzet R (2011). Using plant functional traits to understand the landscape distribution of multiple ecosystem services. Journal of Ecology 99: 135-147. - doi: 10.1111/j.1365-2745.2010.01753.x

LeMaster DC, Owubah CE (2000). Nation states and forest tenures An assessment of forest policy tools in Eastern European countries. In: "Forging a new framework for sustainable forestry: recent 
developments in European forest law" (Schmithuesen F, Herbst P, Le Master DC eds). IUFRO World Series 10: 28-38.

Li C, Liu J, Lafortezza R, Chen J (2011). Managing forest landscapes under changing global scenarios. In: "Landscape ecology in forest management and conservation: challenges and solutions for global change" (Li C, Lafortezza R, Chen J eds). Higher Education Press, Springer, New York, USA, pp. 3-21.

Lindenmayer DB, Franklin JF (2002). Conserving forest biodiversity. A comprehensive multiscaled approach. Island Press, Wasshington, DC, USA, pp. 351 .

Lindenmayer DB, Fischer J (2007). Tackling the habitat fragmentation panchreston. Trends in Ecology and Evolution 22: 127-132. - doi: 10.1016/j.tree.2006.11.006

Luque S, Saura S, Fortin MJ (2012). Landscape connectivity analysis for conservation: insights from combining new methods with ecological and genetic data. Landscape ecology 24: 153157. - doi: 10.1007/s10980-011-9700-5

Makhzoumi J, Pungetti G (1999). Ecological landscape design and planning: the Mediterranean context. E and FN Spon, London, UK

Mata C, Hervás I, Herranz J, Suárez F, Malo JE (2005). Complementary use by vertebrates of crossing structures along a fenced Spanish motorway. Biological Conservation 124: 397-405. doi: 10.1016/j.biocon.2005.01.044

McGarigal K, Tagil S, Cushman SA (2009). Surface metrics: an alternative to patch metrics for the quantification of landscape structure. Landscape Ecology 24: 433-450. - doi: 10.1007/ s10980-009-9327-y

Mendoza MA, Fajardo J, Zepeta J (2005). Landscape based forest management, a real world case study from Mexico. Forest Ecology and Management 209: 19-26. - doi: 10.1016/j.foreco. 2005.01.007

Moreira F, Russo D (2007). Modelling the impact of agricultural abandonment and wildfires on vertebrate diversity in Mediterranean Europe. Landscape Ecology 22 (10): 1461-1476. - doi 10.1007/s10980-007-9125-3

Moreira F, Viedma O, Arianoutsou M, Curt T, Koutsias N, Rigolot E, Barbati A, Corona P, Vaz P, Xanthopoulos G, Mouillot F, Bilgili E (2011). Landscape - wildfire interactions in southern Europe: implications for landscape management. Journal of Environmental Management 92 (10): 2389-2402. - doi: 10.1016/j.jenvman.2011.06. 028

Naveh Z (1995). Interactions of landscapes and cultures. Landscape and Urban Planning 32: 43
54. - doi: 10.1016/0169-2046(94)00183-4 Parrotta J, Agnoletti M (2007). Traditional forest knowledge: challenges and opportunities. Forest Ecology and Management 249: 1-4. - doi: 10.1016/j.foreco.2007.05.022

Perera AH, Baldwin DLB (2000). Spatial patterns in the managed forest landscape of Ontario. In: "Ecology of a managed terrestrial landscape. Patterns and processes of forest landscapes in Ontario" (Perera AH, Euler D, Thompson ID and Ontario Ministry of Natural Resources eds). UBC Press, Vancouver, BC, Canada, pp. 74-99. Puddu G, Falcucci A, Maiorano L (2012). Forest changes over a century in Sardinia: implications for conservation in a Mediterranean hotspot. Agroforestry Systems 85: 319-330. - doi: 10.1007/s 10457-011-9443-y

Romano F (2007). Forest tenure changes in Africa: making locally based forest management work. Unasylva 228 (58): 11-17.

Rotherham ID (2007). The implications of perceptions and cultural knowledge loss for the management of wooded landscapes: a UK case-study. Forest Ecology and Management 249: 100-115 doi: 10.1016/j.foreco.2007.05.030

Sanderson J, Harris LD (2000). Landscape ecology: a top-down approach. Lewis, Washington, DC, USA.

Sanesi G, Padoa-Schioppa E, Lorusso L, Bottoni L, Lafortezza R (2009). Avian ecological diversity as an indicator of urban forest functionality. results from two case studies in Northern and Southern Italy. Arboriculture \& Urban Forest 35: 80-86. [online] URL: http://www.researchgate.net/publication/230753035 Avian Ecological_Diversity_as_an_Indicator_of_Urban_Forest Functionality. Results from_Two_Case_Studies_in_Northern_and_Southern_Italy/file/d912f5 0b7941c51bbc.pdf

Scarascia-Mugnozza G, Oswald H, Piussi P, Radoglou K (2000). Forests of the Mediterranean region: gaps in knowledge and research needs. Forest Ecology and Management 132: 97-109. doi: 10.1016/S0378-1127(00)00383-2

Scheller RM, Mladenoff DJ (2007). An ecological classification of forest landscape simulation models: tools and strategies for understanding broad-scale forested ecosystems. Landscape Ecology 22: 491-505. - doi: 10.1007/s10980-0069048-4

Schooley RL, Wiens JA (2004). Movements of cactus bugs: patch transfers, matrix resistance, and edge permeability. Landscape Ecology 19:801-810. - doi: 10.1007/s10980-005-0093-2

Stephens SL, Millar CI, Collins BM (2010). Operational approaches to managing forests of the future in Mediterranean regions within a context of changing climates. Environmental Research Letters 5: 1-9.

Suzuki N, Olson DH (2008). Options for biodiversity conservation in managed forest landscapes of multiple ownerships in Oregon and Washington, USA. Biodiversity and Conservation 17: 1017-1039. - doi: 10.1007/s10531-0079301-4

Tanentzap AJ, Bazely DR, Lafortezza R (2010). Diversity-invasibility relationships across multiple scales in disturbed forest understoreys. Biological Invasions 12: 2105-2116. - doi: 10.1007/ s10530-009-9612-3

Torras O, Saura S (2008). Effects of silvicultural treatments on forest biodiversity indicators in the Mediterranean. Forest Ecology and Management 255: 3322-3330. - doi: 10.1016/j.foreco.2008. 02.013

Turner MG (1989). Landscape ecology: the effect of pattern on process. Annual Reviews in Ecology, Evolution and Systematics 20: 171-197. doi: 10.1146/annurev.es.20.110189.001131

Turner MG, Gardner RH, O’Neill RV (2001). Landscape ecology in theory and practice: pattern and process. Springer, New York, USA.

Turner MG (2010). Disturbance and landscape dynamics in a changing world. Ecology 91: 2833-2849. - doi: 10.1890/10-0097.1

Van Eetvelde V, Antrop M (2004). Analyzing structural and functional changes of traditional landscapes - two exaples from southern France. Landscape and Urban Planning 67: 79-95. - doi: 10.1016/S0169-2046(03)00030-6

Vos W, Stortelder A (1992). Vanishing Tuscan landscapes. Landscape ecology of submediterranean - montane Area (Solano Basin, Tuscany). Pudoc Scientific Publishers, Wageningen, The Netherlands.

Wu J, Hobbs RH (2007). Key topics in landscape ecology. Cambridge University Press, Cambridge, UK.

Wulder MA, White JC, Andrew ME, Seitz NE, Coops NC (2009). Forest fragmentation, structure, and age characteristics as a legacy of forest management. Forest Ecology and Management 258:1938-1949. - doi: 10.1016/j.foreco.2009.07. 041

Zheng D, Heath LS, Ducey MJ, Butler B (2010). Relationships between major ownerships, forest aboveground biomass distributions, and landscape dynamics in the New England Region of USA. Environmental Management 45: 377-386. - doi: 10.1007/s00267-009-9408-3 